\title{
Стовбур головного мозку: фізіологічні та патологічні аспекти
}

\author{
І.С. Зозуля, А.І. Зозуля, А.О. Волосовець
}

Національний університет охорони здоров'я України імені П.Л. Шупика, Київ, Україна

\section{Функціональна значимість стовбура головного мозку}

Стовбур головного мозку (СГМ) являє собою невеликий витягнутий у довжину анатомічний утвір, що з'єднує спинний мозок із відділами головного мозку (ГМ) в задній черепній ямці, вентральніше мозочка, з яким з'єднаний ножками мозочка. У СГМ входять довгастий мозок, міст і середній мозок. СГМ має найбільше значення у забезпечені життєво важливих функцій.

Основу СГМ становить ретикулярна формація (РФ) - сітка дифузного скупчення нейронів, розміщених у центральній частині довгастого мозку, моста і середнього мозку, яка заповнює простір між ядрами черепних нервів (ЧН), тілами олив і зв'язує волокна висхідних і нисхідних шляхів. Її нейрони отримують еферентну інформацію від спинного мозку, ядер чН, мозочка і ГМ і надсилають аферентну інформацію (імпульси) з цих структур. Широкі зв'язки цих нейронів забезпечують всебічний вплив на більшість нейрональних процесів.

СГМ включає ядра III-IX пар ЧН і їх внутрішньомозкові волокна. У СГМ $\epsilon$ групи нейронів, що $\epsilon$ основним джерелом норадренергічної, дофамінергічної і серотонінергічної іннервації більшої частини мозку. Крім РФ, у СГМ розміщені оливи і червоні ядра.

СГМ - складна, але високоорганізована структура, яка контролює моторні і сенсорні функції, дихання, функцію серцево-судинної системи, процеси сну і неспання, а головне - свідомість. Таким чином, навіть невелике ураження СГМ може викликати тяжкі неврологічні порушення.

\section{Основні функції РФ}

РФ забезпечує активацію ГМ для забезпечення різних рівнів активності (неспання):

- модулюючий вплив на сегментарні рефлекси розтягнення і м'язовий тонус, спрямовані на здійснення контролю рухової активності;

- координація вегетативних функцій, таких як дихання і серцево-судинна функція;

- модуляція сприйняття болю.

\section{Основні функції довгастого мозку}

Довгастий мозок (bulbus) являє собою продовження спинного мозку. У ньому розміщуються ядра нижніх ЧН (переважно IX, X, XI і XII) і нижні оливи. Провідні шляхи задніх стовпів перехрещуються у центральних відділах довгастого мозку, формуючи медіальну петлю. У той самий час кортико-спінальні шляхи перехрещуються у вентральній частині довгастого мозку і йдуть в каудальному напрямку. Разом із мостом довгастий мозок забезпечує такі життєво важливі функції, як травлення, дихання, регуляція серцевого ритму й артеріальний тиск.

\section{Функції моста}

Міст розміщений вентральніше довгастого мозку і являє собою утворення вентральної поверхні СГМ. Він вміщує ядра V, Vl, VII I VIII пар ЧН, а також велику кількість нейронів, які передають інформацію про рухи від лобних часток великих півкуль до мозочка (фронто-понто-церебральний шлях). Другою функціональною одиницею $\epsilon$ забезпечення шляхів моста і контролю рухів очей (медіальний продольний шлях), а також слухові шляхи.

\section{Функції середнього мозку}

Це найбільш ростральний відділ СГМ, що має найменші розміри. Він відіграє важливу роль у контролі рухів очей і коорди- нації зорових і слухових рефлексів. Включає ядра III і IV пар ЧН. Другими структурами $є$ червоні ядра і чорна субстанція.

Водопровідна субстанція має вплив на свідомість і сприйняття болю. У СГМ розміщуються ядра всіх ЧН, за винятком зорового нерва (II пара), волокна якого йдуть до таламусу і нюхового (I пара), волокна якого закінчуються у нюховій цибулині.

\section{Основні функції ЧН}

Забезпечують:

- моторні функції та загальну чутливість;

- особливі види чутливості - зір, слух, смак;

- парасимпатичну іннервацію внутрішніх органів.

\section{Основні суб'єктивні і об'єктивні}

\section{симптоми ураження СГМ}

Суб'єктивні симптоми: двоїння в очах, запаморочення, нудота, порушення координації, порушення ходи, заніміння обличчя, осиплість голосу, порушення ковтання і мови.

Об'єктивні симптоми: дисфункція декількох ЧН: параліч погляду, ністагм, симпатична дисфункція (синдром Паріно), зниження слуху, дисфалгія, дизартрія, дисфонія, девіація й атрофія язика, альтернуючі синдроми (параліч лицьових м'язів або порушення чутливості обличчя з одного боку, а на протилежному боці тіла сенсорні або моторні порушення, іпсілатеральні геміпарези й атаксія, пригнічення свідомості і кома (при двобічних ураженнях СГМ), ізольоване ураження VI і VII пар ЧН частіше виникає внаслідок периферичного, а не центрального, характеру.

Захворювання, які можуть викликати ураження СГМ: пухлини, ішемія/інфаркт, крововилив, судинна мальформація, демієлінізуючі, запальні захворювання (інтрааксіальні ураження). Екстрааксіальні ураження: невринома слухового нерва, менінгома, хордома, аневризми, епідермоїд, арахноїдальна кіста.

\section{Кровоносна система СГМ}

Довгастий мозок кровопостачається хребтовими артеріями та їх гілками. Вони діляться на парамедіанні бульбарні і латеральні бульбарні артерії. Парамедіанні бульбарні артерії відходять безпосередньо від хребтової артерії і кровопостачають структури продовгуватого мозку, розміщені по середній лінії. Крім того, у кровопостачанні довгастого мозку, його нижніх відділів беруть участь гілки передньої спінальної артерії. Латеральна частина кровопостачається латеральними бульбарними гілками хребцевої артерії або задньої нижньої мозочкової артерії.

Міст кровопостачається гілками базилярної артерії, які мають три типи: парамедіанні, що кровопостачають медіально-базальні відділи моста, включаючи ядра моста, кортикоспінальні волокна і медіальну петлю. Короткі огинаючі артерії кровопостачають латеральні відділи моста, а також верхню і середню ножки мозочка. Довгі огинаючі артерії разом із гілками передньої нижньої мозочкової артерії і верхньої мозочкової артерії кровопостачають покришку і дорсолатеральний відділ моста.

Середній мозок кровопостачається гілками верхньої мозочкової артерії, задньої мозочкової артерії, задньої сполучної артерії і передньої ворсинчатої артерії. Вони також діляться на парамедіанні, що кровопостачають медіальні (серединні) структури й довгі та огинаючі гілки, які кровопостачають дорсальні і латеральні відділи середнього мозку. 


\section{Синдроми ураження СГМ}

Медіанний синдром довгастого мозку (синдром Дежеріна) характеризується так: на боці ураження виникає парез язика (XII пара ЧН) з його девіацією у бік ураження. На протилежному боці - геміплегія та втрата суглобово-м'язової і вібраційної чутливості.

При двобічному уражені (інфаркт довгастого мозку) у клінічній картині - тетраплегія (при збережені функції мімічних м'язів), повний параліч язика, повна втрата суглобово-м'язової і вібраційної чутливості. Пацієнт неспроможний розмовляти, хоча свідомість у нього повністю збережена.

Латеральний синдром (синдром Валенберга) відмічається при уражені довгастого мозку і супроводжується втратою больової і температурної чутливості на обличчі (V пара ЧН) на боці ураження, паралічем піднебіння, глотки і голосових зв'язок із розвитком дисфагії і дизартрії внаслідок ураження ядер або волокон IX і X пар ЧН.

На боці ураження - синдром Горнера, атаксія і дисметрія. На протилежному боці тіла — втрата больової і температурної чутливості. Відмічають запаморочення, нудоту, блювання, ністагм. Можуть виникати ікання, двоїння і однобічний головний біль у потиличній ділянці.

Синдром Мільяра - Гублера розвивається при ураженні парамедіанного відділу моста (вентральний синдром моста). Виявляється на боці ураження паралічем латерального прямого м'яза ока з розвитком двоїння (IV пара ЧН), периферичним парезом верхніх і нижніх мімічних м'язів (VII пара ЧН), на протилежному боці - геміплегією зі збереженням функції мімічних м'язів на цьому боці.

Синдром Фовілля, або нижній дорсальний синдром моста, - розвивається в результаті ураження дорсального відділу покришки нижньої частки моста. При цьому на боці ураження відмічають парез верхніх і нижніх мімічних м'язів (VII пара ЧН), параліч горизонтального погляду (VII пара ЧН) і медіанної РФ. На протилежному боці тіла — геміплегія при збереженні функції лицьових м'язів.

Верхній дорсальний синдром моста, або синдром Раймона - Сестана, характеризується на боці ураження атаксією в комбінації з грубим інтенційним тремором. Має місце ураження жувальних м'язів у поєднанні з втратою чутливості на обличчі (V пара). На одному боці тіла відбувається втрата всіх видів чутливості, а з протилежного боку - парез з ураженням лицьових м'язів. Може виникати парез горизонтального погляду.

Вентральний синдром середнього мозку, або синдром Вебера (ураження парамедіанної частки), супроводжується ураженням на своєму боці окорухових м'язів, птозом у поєднанні з розширенням зіниці (III пара ЧН), на протилежному боці тіла геміплегія із залученням нижньої частки мімічних м'язів.

Синдром Бенедікта, або дорсальний синдром середнього мозку, розвивається у результаті ураження покришки середнього мозку і характеризується на боці ураження - паралічем окорухових м'язів, птозом, розширенням зіниці (III пара ЧН), на протилежному боці - мимовільними рухами, інтенціальним тремором, атаксією і хореєю. При масивному ураженні на протилежному боці - геміпарез і геміанестезія.

Дорсальний синдром середнього мозку характеризується на боці ураження симптомом Горнера, грубим тремором, який буває і в спокої, але підсилюється при рухах. При ураженні мозочкової ніжки і червоного ядра можуть розвиватися двобічний тремор і атаксія. На протилежному боці тіла — втрата всіх видів чутливості.

Синдром верхівки базилярної артерії виникає в результаті інфаркта середнього мозку, таламуса і часток скроневої і потиличної часток. При цьому найчастіше відмічають порушення рухів очей (параліч вертикального погляду - вгору, вниз або в обидва боки), косу девіацію, спазм конвергенції (VI пара ЧН), конвергентно-ретракційний ністагм, ретракцію верхніх повік. Розвиваються зорові порушення у вигляді звуження зіниць зі слабкістю реакції на світло, ектопія зіниць, овальна форма зіниць. Третім дуже важливим симптомом $\epsilon$ пригнічення свідомос- ті і порушення поведінки: сопор, сомналенція, апатія, зниження уваги, порушення пам'яті, ажитований делірій.

Зорові порушення характеризуються гомонімною геміанопсією, корковою сліпотою, синдромом Балінта (порушення розпізнавання форми, кольорова агнозія).

Окрему форму становить синдром «закритої людини» (англ. locked-in syndrome), який розвивається при двобічному ураженні вентральних відділів СГМ. Найчастіша його причина інфаркт мозку, крововилив у мозок, травма, центральний понтинний мієліноз, пухлини, енцефаліт. У результаті двобічного ураження кортикоспінальних трактів у вентральних відділах моста розвивається тетраплегія, а у результаті ураження кортикобульбарних трактів пацієнт не може говорити, настає параліч мімічних м'язів. Горизонтальні рухи очей також неможливі (VI пара ЧН). Свідомість збережена, оскільки РФ збережена. Зберігаються вертикальні рухи очей і моргання ними, оскільки над'ядерні окорухові шляхи збережені. Пацієнт може спілкуватися з навколишніми за допомогою рухів повік, а в іншому абсолютно нерухомий.

Синдром Паріно - також дорсальний синдром середнього мозку, або синдром чотирьох горбів, - ураження верхніх горбиків і прилежних структур. Відмічають утруднення погляду вгору, порушення погляду вдалечінь. Характерна тетрада симптомів: 1) параліч погляду вгору і порушення акомодації при збережені других рухів очей; 2) розмір зіниць варіює від нормальних до широких із дисоціацією - відсутність реакції зіниць на світло при збереженні звуження їх при акомодації; 3) ретракція повік; 4) конвергентно-ретракційний ністагм. Причинами швидше за все $\epsilon$ пухлини шишковидної залози, інсульт, травма, гідроцефалія, розсіяний склероз, тиреоїдна офтальмоплегія, міастенія, синдром Гійєна — Баре або вроджений характер.

Між'ядерна офтальмоплегія характеризується порушенням горизонтального погляду (VI, III пари ЧН). Найчастіше виникає при розсіяному склерозі або в осіб похилого віку при оклюзії базилярної артерії. Може виникати при передозуванні барбітуратів, фенітоїну, амітриптиліну, рідше - при міастенії, енцефаліті Верніке, синдромі Гійєна - Баре. У клінічній картині на боці ураження - параліч приведення очного яблука (ураження прямого м'яза), горизонтальний ністагм відведеного ока на протилежному боці. При двобічному ураженні - недоведення очного яблука в обидва боки. Інколи відмічаються коса девіація очних яблук і вертикальний ністагм. Конвергенція зазвичай збережена.

Бульбарний синдром (бульбарний параліч) - синдром ураження нижніх мотонейронів ядер ЧН (IX-XII). У клінічній картині - параліч м'язів обличчя, піднебіння, глотки, груднинно-ключично-соскоподібного м'яза, верхньої частини трапецієподібного м'яза, м'язів язика. Проявляється дизартрією, дисфонією, осиплістю, гнусавим голосом, звисанням м'якого піднебіння $з$ девіацією язичка, зниженням ковтального рефлексу, слабкістю язика, груднинно-ключично-соскоподібного і трапецієподібного м'язів. Причини ураження - інфаркт, сирінгобульбія, гліома, поліомієліт, енцефаліт, боковий аміотрофічний склероз, прогресуючий бульбарний параліч, менінгіома або нейрофіброма, менінгіт, аневризма, травма шиї, вроджені аномалії (синдром Арнольда - Кіарі).

Псевдобульбарний синдром, або параліч, - ураження верхніх мотонейронів у результаті двобічного ураження кортикобульбарних шляхів вище рівня СГМ. Клініка проявляється дисфагією, дизартрією, парезом язика (без атрофії і фасцикуляцій). Рух піднебіння і глотки часто, навпаки, живіші. Живіший і нижньощелепний рефлекс. Мають місце позитивні підкіркові рефлекси (хватальний, сосальний, хоботковий). Відмічається насильницький плач (рідше сміх) як прояв ураження лобних еферентних волокон, що контролюють емоційну експресію. Цей синдром розвивається внаслідок множинних лакунарних інфарктів або хронічної ішемії в півкулях ГМ, ураження корково-бульбарних шляхів з двох боків. Може розвиватися при боковому аміотрофічному склерозі і розсіяному склерозі. 


\section{Ураження РФ}

При уражені СГМ, його РФ, виникає порушення свідомості.

За ступенем порушення свідомості розрізняють:

1. Приглушення (пацієнт сонливий, може просинатися через легкі подразнення, реакції збережені).

2. Сопор (стан сонливості, пацієнт пробуджується через сильні подразники).

3. Кома (пацієнт не пробуджується):

- кома I - характеризується цілеспрямованою відповіддю на больові подразники, реакція зіниць збережена;

- кома II - реакція на больові подразники зберігається, можлива анізокорія;

- кома III - реакція на больові подразники не цілеспрямована, можливі згинальні і розгинальні рухи;

- кома IV - реакція на біль відсутня, зіниці розширені і не реагують на світло, спонтанне витягування, патологічне дихання.

Існує порушення свідомості без (при анемії, електролітних порушеннях, лихоманці, гіпоксії, інфекціях, інтоксикаціях, метаболічному синдромі) та 3 неврологічними порушеннями (при кровотечі - внутрішньомозковій, субарахноїдальній, епідуральній, субдуральній), ендокардиті з септичною емболією, енцефаліті, мієліті, набряку ГМ, судомному нападі (після нападу), ішемії ГМ - інфаркт, тромбоз).

\section{Оцінка стовбурових функцій при комі}

При огляді хворого, що знаходиться в комі, необхідно звертати увагу на симптоми, які пов'язані з ураженням СГМ (РФ). Це особливо важливо при загрозі вклинення його у задню черепну ямку в результаті підвищеного внутрішньочерепного тиску. Дисфункція СГМ поширюється в рострокаудальному напрямку і закінчується смертю пацієнта при залученні у процес довгастого мозку. При цьому слід проводити заходи щодо зниження внутрішньочерепного тиску.

Для контролю за станом пацієнта використовують такі параметри: психічний статус, дихання, величина зіниць та їх реакція на світло, спонтанні (мимовільні) рухи очей, окулоцефалічний рефлекс при поворотах голови (феномен лялькових очей), окуловестибулярні реакції у відповідь на введення холодної води у вуха, оцінку моторної реакції при натисканні на точку виходу надочного нерва (I точка трійчастого нерва), дослідження других стовбурових рефлексів (рогівковий, блювальний, циліоспінальний). Стан свідомості визначають за шкалою коми Глазго.

Локалізація рівня ураження СГМ представлена в таблиці.

\section{Визначення незворотного ураження СГМ}

Смерть мозку - клінічний діагноз незворотного ураження всіх півкульних і стовбурових функцій. Про повну втрату функції СГМ перш за все свідчить апноетична кома. При цьому всі стовбурові рефлекси (роговичний, зіничний, блювальний, циліоспінальний) відсутні, зіниці середніх розмірів або широкі, ареактивні. Окулоцефалічний та окуловестибулярний рефлекси відсутні. М'язовий тонус знижений, відсутні спонтанні скорочення мімічних м'язів і рухові реакції на больові подразники. Щоб діагностувати смерть мозку, вказані симптоми у дорослих збе- рігаються протягом 6-24 год. Необхідно виключити метаболічні ураження (гіпотермія, артеріальна гіпотензія), передозування лікарських засобів (міорелаксанти, седативні засоби).

\section{Порушення свідомості при деяких захворюваннях}

Гіпо-/гіперглікемія (цукровий діабет в анамнезі, декомпенсація, пов'язана з інфекційними захворюваннями, помилка у застосуванні ліків)

Клінічна картина при гіпоглікемії: пригнічення свідомості від приглушення до коми, виражена пітливість, тахікардія, можливі судоми, при гіперглікемії: прогресуюче порушення свідомості, полідипсія, поліурія, дихання Куссмауля.

Первинна діагностика: лабораторна діагностика (глюкоза в крові, електроліти, глікозильований гемоглобін, С-реактивний білок).

\section{Гіпонатріємія (застосування}

діуретиків, нецукровий діабет)

Клінічна картина: втомлюваність, порушення уваги, порушення ходи, координації, судомні напади, пригнічення свідомості аж до коми, неврологічний дефіцит.

Первинна діагностика: анамнез застосування ліків, лабораторна діагностика ( $\mathrm{Na}, \mathrm{C}, \mathrm{Ca}, \mathrm{Cl}$, осмолярність сироватки крові і сечі).

Застосування лікарських препаратів

(протипаркінсонічних, холінергічних, анальгетиків, протисудомних, протиаритмічних)

Клінічна картина: пригнічення свідомості, відчуття скутості, порушення з боку серця (залежно від препаратів) - брадикардія (тахікардія, гіпо-/гіпертензія, гіпо-/гіпервентиляція).

Первинна діагностика: зібрати анамнез захворювання і застосування медичних препаратів, відповідно до клінічної картини - комп'ютерна томографія (КТ)/магнітно-резонансна томографія (МРТ) ГМ, електрокардіографія, рівень артеріального тиску, порушення ритму серця.

\section{Інтоксикація (наркотичні речовини, лікарські}

препарати, алкоголь, продукти харчування)

Клінічна картина нечітка: пригнічена свідомість, психічні розлади, порушення серцевого ритму, ексикоз, скарги з боку шлунково-кишкового тракту, сліди від уколів на тілі (руці).

Первинна діагностика: зібрати анамнез, скринінг на наркотичні засоби (кров, сеча), визначення алкоголю в крові.

\section{Печінкова кома}

Клінічна картина: напівсвідомість, асцит, жовтяниця, гепатомегалія, апатія, тремор.

Первина діагностика: збір анамнезу (захворювання печінки - вірусний гепатит, новоутворення, алкоголізм, наркоманія). Лабораторна діагностика (клінічний аналіз крові, печінкові проби, коагулограма, електроліти).

\section{Уремія}

Клінічна картина: пригнічена свідомість, сіро-коричневий колір шкіри, уремічний запах, міоклонії.

Первинна діагностика: анамнез (хронічна серцева недостатність, захворювання нирок, інтоксикація).

Таблиця Локалізація рівня ураження СГM

\begin{tabular}{lllll}
\hline \multicolumn{1}{c}{ Клінічна картина } & \multicolumn{1}{c}{ Підкіркові структури } & \multicolumn{1}{c}{ Середній мозок } & Міст & Довгастий мозок \\
\hline Свідомість & Сонливість або сопор & Кома & Кома & Кома \\
\hline Дихання & Чейна — Стокса & Центральна гіпервентиляція & Апноетичне або кластерне & Атактичне \\
\hline Зіниці & Вузькі, реакція збережена & $\begin{array}{l}\text { Середніх розмірів, ареактивне (ураження ядра III парии } \\
\text { ЧН), однобічне розширення і ареактивне (III пара ЧН) }\end{array}$ & Состо тово, ареактивні & $\begin{array}{l}\text { Середніх розмірів, } \\
\text { неправильної форми }\end{array}$ \\
\hline $\begin{array}{lllll}\text { Окулоцефалічний і } \\
\text { окулобульбарні рефлекси }\end{array}$ & У нормі & Відсутні або патологічні & Відсутні або патологічні & Не викликаються \\
\hline Рухові реакції на подразнення & Декортикаційна поза & Децеребраційна поза & Децеребраційна поза або & Реакція відсутня \\
& & & реакція відсутня & \\
\hline
\end{tabular}


Первинна діагностика: анамнез захворювання (ниркова недостатність у стадії декомпенсації). Лабораторні дослідження: клінічний аналіз крові, ниркові проби, коагулограма, електроліти).

\section{Тиреотоксикоз}

Клінічна картина: ажіатація, марення, тахікардія, гіпертермія, правошлуночкова серцева недостатність, м'язова слабкість.

Первинна діагностика: лабораторні дані (тиреотропний гормон, $\mathrm{T}_{3} / \mathrm{T}_{4^{\prime}}$ електроліти), ультразвукова діагностика.

\section{Недостатність надниркових залоз (хвороба Аддісона)}

Клінічна картина: гіпотензія аж до шоку, підвищення температури тіла, дегідратація, електролітні порушення (гіпонатріємія, гіперкаліємія, гіперкальціємія), гіперпігментація, слабкість.

Первинна діагностика: анамнез, лабораторні дослідження (тест на адренокортикотропний гормон, електроліти).

\section{мікседема}

Клінічна картина: пригнічена свідомість від приглушення до коми, гіпотермія, брадикардія, загальна серцева недостатність, суха і шорстка шкіра.

Первинна діагностика: лабораторна (тиреотропний гормон, $\mathrm{T}_{3} / \mathrm{T}_{4^{\prime}}$ електроліти).

\section{Інфекції (бактеріальний менінгіт, вірусний енцефаліт,} насамперед герпес-енцефаліт, септична енцефалопатія)

Клінічна картина: супутні інфекції, втрата свідомості, що розвиваються протягом годин або днів, виникає головний біль, менінгізм, нудота, блювання, світлобоязнь, неврологічний дефіцит, екзантема.

Первинна діагностика: зміна температури тіла, лабораторна діагностика (клінічний аналіз крові, С-реактивний білок, аналіз сечі, посів крові, МРТ з контрастуванням, рентгенографія органів грудної клітки).

\section{Супратенторіальні процеси (крововилив,}

\section{інфаркт, пухлина, абсцес, забій ГМ)}

Клінічна картина: однобічні сенсомоторні порушення, головний біль (крововилив, абсцес), поступово прогресуюча симптоматика (абсцес, пухлина), травма (забій ГМ).

Первинна діагностика: анамнез, клінічна картина, КТ/МРТ ГM.

\section{Гострий демієлінізуючий енцефаломієліт}

Клініка: лихоманка, головний біль, сплутаність свідомості (від апатії до коми), неврологічний дефіцит.

Первинна діагностика: анамнез, МРТ ГМ, краще з контрастуванням, дослідження ліквору.

\section{Генералізований набряк ГМ (при гіпонатріємії, дегідратації, гіпоксії)}

Клінічна картина: порушення свідомості, неврологічний (при високому внутрішньочеревному тиску), згинаючі - розгинаючі синергічні рухи, розширені зіниці.

Первинна діагностика: анамнез, КТ/МРТ ГМ, лабораторна діагностика.

\section{Загальна ішемія ГM}

Серцева недостатність, ексикоз, деменція. Клініка: артеріальна гіпотензія, ціаноз, бліда шкіра. Первинна діагностика: клінічна картина, ЕКГ, АТ, КТ, ехоКГ, лабораторна діагностика, ознаки анемії.

\section{Акінетичний мутизм (при двобічному ураженні лобних часток)}

Клінічна картина: відсутність спонтанних рухів і мови при збереженні свідомості.

Первинна діагностика: анамнез, КТ/МРТ ГМ.

Вегетативний статус, синдром «закритої людини» (псевдокома)

Причини: черепно-мозкова травма.
Клінічна картина: відсутність порушення свідомості при неможливості спілкування.

Первинна діагностика: анамнез (ураження ГМ), МРТ/КT, електроенцефалографія.

Стовбурові синдроми часто відмічають на фоні ішемії СГМ, запальних процесів, метаболічних порушень і новоутворень.

у клінічній картині відмічають перехресне випадіння функцій з іпсілатеральним порушенням ЧН і контралатеральним ураженням глибокого перехресного пірамідного тракту. Часто виявляють іпсілатеральне порушення функції мозочка у вигляді ураження аферентних і еферентних мозочкових шляхів.

\section{Основні стовбурові синдроми}

Середній мозок:

- Синдром Пьєра - Маріфокса: на боці ураження - синдром Горнера, парез лицьового і привідного нервів, на протилежному боці - геміпарез, геміпарестезія.

- Синдром Вебера (ураження вентрального хвостатого ядра, середній мозок): на боці ураження парез окорухового нерва, на протилежному - геміпарез.

- Синдром Бенедикта (верхній синдром червоного ядра, середній мозок): на боці ураження - парез окорухового нерва, на протилежному - геміатаксія, гіперкінези (тремор, підвищений тонус).

- Синдром Нотнагеля (середній мозок): на боці ураження парез окорухового нерва, на протилежному - геміатаксія, парез погляду вгору, геміхореоатетоз.

- Синдром Клода (нижній синдром червоного ядра, середній мозок): на боці ураження - парез окорухового нерва, на протилежному - геміпарез.

Ураження моста:

- Синдром Раймона: на боці ураження - парез відповідного нерва, на протилежному - геміпарез.

- Синдром Раймона - Сестана: на боці ураження - міжядерна офтальмоплегія, на протилежному - геміатаксія, геміпарез, геміпарестезія.

- Синдром Гасперіні (нижня частина покришки, ділянка нижньої мозочкової артерії): на боці ураження - ураження трійчастого нерва, парез лицьового і відвідного нерва.

\section{Довгастий мозок:}

- Синдром Валенберга (інфаркт дорсолатеральної частки довгастого мозку при стенозі верхньої, передньої мозочкової артерії або хребтової артерії): на боці ураження - парез м'якого піднебіння, геміатаксія, синдром Горнера, парез задньої стінки глотки, парез голосових зв'язок.

- Синдром Джексона (медіальний інфаркт довгастого мозку): на боці ураження — парез м'якого піднебіння, парез задньої стінки глотки, парез голосових зв'язок, парез язика, на протилежному - геміпарез.

- Синдром Авелліса: на боці ураження - парез м'якого піднебіння, задньої стінки глотки, голосових зв'язок, на протилежному - геміпарез, геміпарестезія, зниження больової і температурної чутливості.

- Синдром Спіллер: на боці ураження - парез язика, на протилежному - геміпарез, геміанестезія.

- Синдром Мільяра - Гублера (інфаркт каудальної частини моста): на боці ураження - парез відвідного і лицьового нерва, на протилежному - геміпарез і геміанестезія, зниження больової і температурної чутливості.

\section{Розпізнавання ураження відповідно до клініки}

1. Парез погляду: горизонтальний - ураження моста, вертикальний - ураження середнього мозку, офтальмоплегія - центральне ураження моста і середнього моста.

2. Дизартрія, дисфалгія, сенсомоторний дефіцит - ураження зони каудальних ЧН.

3. Запаморочення, порушення рівноваги - порушення зони вестибулярного ядра в довгастому мозку. 
4. Порушення свідомості - тяжкі та/або дифузні ураження СГМ із залученням РФ.

5. Порушення свідомості - ажитація, порушення полів зору, зорові галюцинації, порушення рухів очей і їх моторики, порушення пам'яті, сплутаність свідомості.

Стовбурові епілептичні напади: при розсіяному склерозі, судинних ураженнях, клінічно виявляються довготривалим епілептичним нападом (декілька хвилин), очі активно закриті, рухові порушення, часткове виконання команди під час нападу.

Первинна діагностика: типова клінічна картина, електроенцефалографія.

\section{Висновки}

1. СГМ забезпечує усі важливі життєві функції організму.

2. Ураження окремих відділів СГМ (середній мозок, міст, довгастий мозок) дає відповідну клінічну картину.

3. Одна з головних функцій РФ — підтримання свідомості, активація кори ГМ, модуляція постурального тонусу рухів у нижніх кінцівках.

\section{Список рекомендованої літератури/References:}

1. Rolak L.A. (2014) Neurology Secrets. Binom, 586 p. (In Rus.).

2. Grabowski A. (2016) Emergency neurology. Clinical guidelines. Panfilov Publishing House, 592 p. (In Rus.).

\section{Information about the authors:}

Zozulya Ivan S. - Doctor of Medical Sciences, Professor of the Department of Emergency Medicine of the Shupyk National Healthcare University of Ukraine, Kyiv, Ukraine.

Zozulya Andriy I. - Doctor of Medical Sciences, Professor of the Department of Emergency Medicine of the Shupyk National Healthcare University of Ukraine, Kyiv, Ukraine.

Volosovets Anton 0. - Doctor of Medical Sciences, Associate Professor, Head of the Department of Emergency Medicine of the Shupyk National Healthcare University of Ukraine, Kyiv, Ukraine.

Address for correspondence:

Ivan Zozulya

04112, Kyiv, Dorohozhytska str., 9

E-mail: nmapo.emergency@gmail.com

Надійшла до редакції/Received: 13.06.2021 Прийнято до друку/Accepted: 02.07.2021

ТЕСТОВІ ЗАПИТАННЯ

(один або декілька правильних варіантів відповідей на кожне запитання)

1. Які структури входять до СГМ?
$\square$ кора ГМ
$\square$ середній мозок
$\square$ міст
$\square$ довгастий мозок

2. Ядра яких ЧН розміщуються у довгастому мозку?
$\square \mathrm{I}, \mathrm{II}$
$\square \quad \mathrm{IX}, \mathrm{X}$
$\square \mathrm{XI}, \mathrm{XII}$
$\square$ медіальна петля

3. Які ЧН починаються (ядра) у мості?
$\square \mathrm{I}, \mathrm{II}, \mathrm{III}$
$\square \mathrm{V}, \mathrm{VI}$
$\square \mathrm{VII}, \mathrm{VIII}$
$\square$ медіальний довгастий пучок

4. Ядра яких ЧН знаходяться у середньому мозку?
$\square \mathrm{XI}, \mathrm{XII}$
$\square \quad$ III, IV
$\square$ червоне ядро
$\square$ чорна субстанція

5. У яких структурах залягають ядра I і II пар ЧН?
$\square$ довгастий мозок
$\square$ I - нюхова цибулина
$\square$ II - таламус
IV

6. Як називають синдроми при уражені СГМ?
$\square$ альтернуючі
$\square$ ураження ЧН на боці ураження СГМ
$\square$ пірамідна патологія на протилежному боці
мозочкові порушення на протилежному боці

7. Основні суб'єктивні і об'єктивні симптоми при ураженні СГМ: $\square$ диплопія
$\square$ запаморочення
$\square$ порушення ходьби
$\square$ дисфункція декількох ЧН
$\square$ дисфагія, дизартрія
$\square$ девіація язика з атрофією
$\square$ біль уживоті

8. Кровопостачання СГМ відбувається:
$\square$ хребтовими артеріями та їх гілками
$\square$ парамедіанними бульбарними артеріями
$\square$ латеральними бульбарними артеріями
$\square$ передньою спінальною артерією
$\square$ середньою мозковою артерією

9. Визначення синдрому Вебера:

$\square$ на боці ураження СГМ параліч окорухового нерва

$\square$ на протилежному боці тіла - геміплегія із залученням мімічних м'язів

$\square$ синдром Горнера

10. Синдром Валенберга:

$\square$ на боці ураження - втрата больової і температурної чутливості, параліч піднебінної завіси, глотки і голосових зв'язок

$\square$ на боці ураження - атаксія, дисметрія

$\square$ на протилежному боці - втрата больової і температурної чутливості

$\square$ запаморочення, ністагм

11. Що таке синдром базилярної артерії?

$\square$ ураження середнього мозку, таламуса, часток скроневої і потиличної часток

$\square$ ареактивність, порушення свідомості

$\square$ амнезія

$\square$ порушення рухів очей, гомонімна геміанопсія, коркова сліпота

$\square$ порушення кольорового зору 
парез, розлади чутливості, рефлекси варіабельні, помірно виражені

12. Синдром Паріно (ураження чотирьох горбиків у середньому мозку):

$\square$ параліч погляду вгору й акомодація

$\square$ відсутність реакції зіниць на світло при нормальній реакції на конвергенцію

$\square$ ретракція повік

$\square$ конвергентно-ретракційний ністагм

13. Що таке бульбарний синдром (параліч)?

$\square$ ураження IX-XII пар ЧН у довгастому мозку

$\square$ параліч м'язів обличчя, піднебіння, глотки, гортані, груднино-ключично-соскоподібного м'язу

$\square$ дизартрія, дисфагія, осиплість голосу, носовий відтінок голосу, звисання м'якого піднебіння з девіацією язичка, зниження глоткового рефлексу

$\square$ параліч груднинно-ключично-соскоподібного м'яза

14. Що таке псевдобульбарний синдром (параліч)?

$\square$ двобічне ураження кортикобульбарних шляхів вище рівня СГМ

$\square$ дисфагія, дизартрія, парез язика (без атрофії і фасцикуляцій)

$\square$ рефлекторні рухи м'якого піднебіння живі (підсилені)

$\square$ лобні знаки (хоботковий, сосальний, Маринеску - Родовича)

насильницький плач і сміх кашель

15. Функції РФ:

$\square$ забезпечує свідомість

$\square$ активуючий вплив на ГМ

$\square$ модуляційний вплив на тонус у нижніх кінцівках, постуральний тонус

$\square$ контроль рухової активності

$\square$ контроль вегетативних функцій

$\square$ модуляція сприйняття болю

16. Оцінка стовбурових функцій у стані коми:

$\square$ дихання

$\square$ величина зіниць та їхня реакція на світло

$\square$ спонтанні рухи очей

$\square$ окулоцефалічний і окуловестибулярний рефлекси

$\square$ моторна реакція на біль

17. Ознаки незворотного функціонування СГМ:

$\square$ відсутність роговичного, зіничного, блювального, циліоспінального рефлексів

$\square$ зіниці широкі, ареактивні

м'язовий тонус низький

$\square$ відсутність спонтанних рухів на біль

18. Цей стан може продовжуватися:
6-24 год
1-5 год
24-72 год

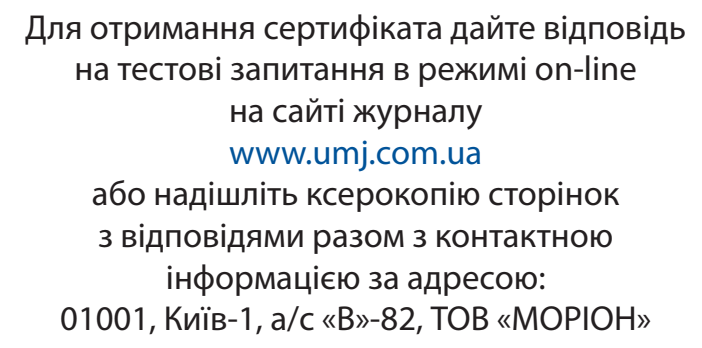

ПІБ

Поштова адреса: індекс
область
район
місто
вулиця
будинок
квартира
Телефон
E-mail

